\title{
Summary of Papers Presented at the Second Conference of the International Research Forum on Monetary Policy
}

Gregg Forte, of the Board's Division of Research and Statistics, prepared this article.

The International Research Forum on Monetary Policy held its second conference on November 14 and 15,2003 . The organization is sponsored by the European Central Bank (ECB); the Board of Governors of the Federal Reserve System (FRB); the Center for German and European Studies (CGES), at Georgetown University, in Washington, D.C.; and the Center for Financial Studies (CFS), at the Goethe University, in Frankfurt. It was formed to encourage research on monetary policy issues that are relevant from a global perspective, and it organizes conferences that are held alternately in the euro area and the United States.

The 2003 conference, held in Washington, D.C., featured ten papers. ${ }^{1}$ Among the topics examined were the Great Inflation of the 1970s in the United States and the influence of learning, or adjustment of expectations, on policy outcomes; the tradeoffs between rules-based and discretionary monetary policy; the 1999 formation of the European Economic and Monetary Union and whether it altered the degree of economic integration between the United States and the euro area; the potential benefits of greater competition in the euro area; and optimal monetary policy in an international setting. This summary discusses the papers in the order presented at the conference. $^{2}$

\footnotetext{
Note. The author of this article thanks Dale Henderson and the authors of the conference papers for their assistance in its preparation and Christopher J. Erceg, Glenn Follette, Christopher J. Gust, Daniel E. Sichel, and Robert J. Tetlow for helpful comments.

1. The organizers of the forum's 2003 conference were Ignazio Angeloni (ECB), Matthew Canzoneri (CGES), Dale Henderson (FRB), and Volker Wieland (CFS).

2. A list of the papers appears at the end of this article along with an alphabetical list of authors and their affiliations at the time of the conference. For a limited period, the papers will be available at www.federalreserve.gov/events/conferences/irfmp2003/default.htm. In addition, a revised version of each conference paper will be available in one of the following series of working papers: the
}

\section{INFORMATION AND LEARNING}

In the conference's first session, "Information and Learning," two papers considered the conduct of monetary policy during the high inflation and high unemployment (stagflation) of the 1970s. In both papers, the authors note the wide agreement today that underlying productivity growth had fallen in the early 1970 s and that monetary policy was too accommodative given the resultant narrowing of the output and unemployment gaps. Fabrice Collard and Harris Dellas create a model that can explain the conduct of monetary policy in the 1970s if the central bank is fairly insensitive both to expectations of rising inflation and to any perception of a wide output gap and is also highly uncertain about potential output.

Athanasios Orphanides and John C. Williams trace the high-inflation episode to monetary policy mistakes that had started earlier, in the mid-1960s. They argue that, from the mid-1960s through the late 1970s, the Federal Reserve paid excessive attention to stabilizing output and employment around levels that later proved to have been too high. This policy mistake loosened inflation expectations and gave rise to the stagflation of the 1970s. The authors believe that the recognition of this error at the end of the decade led policymakers to place greater emphasis on the stabilization of prices and of inflation expectations.

\section{Collard and Dellas}

In their paper, "The Great Inflation of the 1970s," Collard and Dellas evaluate three alternative explanations of the loose policy of the 1970s:

Federal Reserve Board's International Finance Discussion Papers (www.federalreserve.gov/pubs/ifdp/2004/default.htm), the European Central Bank's Working Paper Series (www.ecb.int/pub/wp/wp.htm), and the Center for Financial Research's CFS Working Paper series (www.ifk-cfs.de/English/homepages/h-cfsworkingpaper.htm). 
1. Policy was biased toward creating inflation surprises as a means of lowering unemployment (or "policy opportunism," for short)

2. Policy reacted strongly to increases in expected inflation but suffered from erroneous information that hid the actual drop in underlying productivity growth and hence in potential output; thus, policy was only inadvertently loose ("imperfect information")

3. Policy reacted weakly to increases in expected inflation ("weak reaction to inflation")

The authors employ a New Neoclassical Synthesis model, specified to produce a unique equilibrium, in which policymakers follow a standard HendersonMcKibbin-Taylor rule to set the policy rate. Finding the conditions under which such a model will generate the 1970s volatility in inflation and in other macroeconomic variables such as output and investment, the authors say, may indicate which of the policy explanations is most relevant.

In the monetary policy rule, the policy variable set by the authority in the present period is a function of three other variables: the policy variable in the preceding period, the inflation gap (the gap between inflation expected in the next period and the steadystate rate), and the output gap (the gap between current output and potential output). Potential output is not observable, and the monetary authority learns only gradually about shocks to it.

In looking for a specification of their model that will reproduce the conditions of the 1970s, the authors vary the shocks to, and the degree of uncertainty about, potential output and the speed at which the monetary authority responds to changes in the inflation gap and the output gap. In the first (baseline) trial, the authors assume a reaction speed about the same as that commonly associated with the VolckerGreenspan era, that is, a coefficient of 1.5 on the inflation gap and 0.5 on the output gap. (A value of at least 1 for the coefficient on the inflation gap is necessary for the model to avoid an indeterminate equilibrium - that is, the possibility of reaching various stable but undesirable economic outcomes.) They select a supply shock-a reduction in productivity growth-sufficient to generate an increase of 5-6 percentage points in the inflation rate. They find that with a supply shock of about 30 percent and a high degree of uncertainty about the output gap, the model produced the desired increase in inflation. Moreover, this specification is quite successful in predicting the volatility in variables such as investment, output, and inflation. Its main weakness is in its exaggeration of the severity of the predicted recession and in its requirement of a very large shock.

The authors also examine the performance of the model under perfect information and a specification of the Henderson-McKibbin-Taylor rule that contains a reaction to inflation that is too weak and thus leads to indeterminate equilibriums. This specification also performs quite well: It generates a large and persistent increase in the inflation rate after a large productivity slowdown (a supply shock of about 12 percent) and predicts an amount of macroeconomic volatility comparable to that observed in the real world. The main weakness of this specification is, again, its exaggeration of the severity of the predicted recession.

The results from these two specifications suggest that one need not appeal to the first explanation (policy opportunism) to explain the inflation of the 1970s. The results also suggest that it may not be possible to discriminate between the second explanation (substantial imperfect information plus strong reaction to expected inflation) and the third (good information but weak reaction to expected inflation) - the data lend considerable support to both. The third explanation implies that economic outcomes would have been much better had the central bank's reaction to inflation been stronger, whereas the second explanation implies that, given uncertainty about the true output gap, even a strong reaction to inflation would not have sufficed to keep inflation in check in the face of a very large, unobserved productivity slowdown.

\section{Orphanides and Williams}

In "The Decline of Activist Stabilization Policy: Natural Rate Misperceptions, Learning, and Expectations," Orphanides and Williams reexamine the sources of U.S. stagflation in the 1970s and of the subsequent improvement in macroeconomic performance.

The authors trace the policy failure of the 1970s to what they term the "activist" approach to macroeconomic policy - the so-called New Economics, which became popular during the 1960s. According to this approach, the management of aggregate demand could counteract any shortfalls or excesses relative to the economy's potential and thus attain the dual goals of macroeconomic policy: sustained prosperity and price stability. The enviable performance of the U.S. economy in the first half of the 1960s appeared to validate the promise of the New Economics. But in the second half of the 1960s, the prosperity was 
purchased at the cost of rising inflation; and by the 1970s, the economy had fallen into stagflation-high unemployment accompanied by high inflation.

Orphanides and Williams argue that in the 1960s and 1970s the Federal Reserve attempted a tight stabilization of the unemployment rate near an estimate of the natural rate that was far too low. The resulting gradual rise of inflation adversely influenced private agents' expectations, which in turn put further upward pressure on prices. This combination, rather than only adverse supply shocks such as a drop in productivity, explains much of the performance of the U.S. economy in the 1970s. That is, the misperception of the natural rate caused policymakers to be far too optimistic about how low they could push the unemployment rate without generating inflation pressures. Policy, influenced by the New Economics, remained excessively stimulative and contributed to rising inflation. The rise in inflation expectations amplified and propagated this initial policy error and led to stagflation.

In the authors' model, private agents have only imperfect knowledge of the structure of the economy and of policy, but in a process of perpetual "learning," they continually update their beliefs. This learning process causes the direct effects of policy errors to alter inflation expectations and thereby to further influence the economy. According to the model, the combination of stimulative monetary policy and rising inflation during the late 1960s and 1970s contributed to public confusion regarding the Federal Reserve's objectives and the behavior of inflation. Inflation expectations were initially well anchored because of the price stability of the 1950s and early 1960s; but they changed during the late 1960s, when policy errors and the resulting rise in inflation caused them to drift upward. By the time that the supply shocks of the 1970s hit, expectations of rising inflation exacerbated the effects of the shocks and contributed to stagflation.

The authors point out that, although some observers suggest that monetary policy was inherently destabilizing in the pre-1979 period, the results in their paper do not rely on such a condition. They note that their policy rule for the pre-1979 period, which is based on real-time data and forecasts, features a response of nominal rates to inflation that is greater than one-for-one, a result consistent with stability in the model economy.

Orphanides and Williams show that, had monetary policy not reacted as aggressively to perceived unemployment gaps as it did, inflation expectations would have remained stable, and the stagflation of the 1970s would have been avoided despite the dramatic increases in oil prices and the productivity slowdown during that period. According to the model, a less aggressive reaction to the unemployment gap would have done a better job of stabilizing inflation and unemployment in the 1970s.

By end of the 1970s, according to the authors, monetary policy makers appeared to recognize the nature of the problem. Faced with high and rising inflation, they changed course, turning away from the fine-tuning of demand management advocated by the New Economics and concentrating instead on the goal of price stability. After the costly disinflation of the early 1980s, the change in focus contributed to a new era of relatively stable inflation and unemployment.

\section{MONETARY AND FISCAL POLICY}

In the conference's second session, "Monetary and Fiscal Policy," three papers addressed the design of optimal policy. In the first paper, Pierpaolo Benigno and Michael Woodford propose a model that can address simultaneously the basic policy problems (including sticky prices and incentives-distorting taxes) of the monetary and fiscal authorities. In the second paper, Susan Athey, Andrew Atkeson, and Patrick J. Kehoe consider a compromise between the desirability of allowing the central bank discretion to act on private information and the desirability of preventing the central bank from stimulating output with unexpected inflation. And in the third, Jordi Galí, J. David López-Salido, and Javier Vallés attempt to reconcile the fact that a rise in government spending leads to higher consumption with predictions to the contrary from neoclassical theory and real-business-cycle models.

\section{Benigno and Woodford}

In "Optimal Monetary and Fiscal Policy: A LinearQuadratic Approach," Benigno and Woodford observe that models of optimal policy for the two types of stabilization are typically developed in mutual isolation. Monetary policy models typically ignore the consequences of monetary policy for the government budget. This approach can be justified under the assumption that nondistorting sources of government revenue exist, but it is inappropriate if, as emphasized in the literature on optimal tax policy, all available sources of revenue create distortions. Likewise, models of optimal fiscal policy at most include elements of monetary policy only under the 
simplifying assumption that prices are flexible and hence clear markets, so that tax rates affect output without regard to aggregate demand. Investigations of optimum monetary policy, however, confront the excesses and deficiencies created by prices that do not immediately adjust.

The authors propose to determine how the results of these two types of model would need to be modified if they are combined as two aspects of a single general-equilibrium model and if each aspect includes the more realistic concerns of the other. The authors point out that they approach the task differently from some recent papers that have combined optimal monetary and fiscal policy with sticky prices. The differences are that the present paper (1) uses staggered pricing of the sort appearing in models with explicit microfoundations and in some empirical work on the monetary transmission mechanism, (2) obtains analytical and not purely numerical results by virtue of the linear-quadratic approach, (3) derives optimal targeting rules for monetary and fiscal policy that yield a single rational-expectations equilibrium and optimal policy responses to any shock.

The authors find that, in their model, the volatility of inflation and tax rates is highly sensitive to the frequency with which prices change (the degree of stickiness). In their baseline case, prices change at just less than six-month intervals (a rate they say is consistent with survey results). Under fully flexible prices, the optimal response of inflation to a fiscal shock is eighty times as large as in the baseline case, and the long-run tax rate has no response. Even if sticky prices adjust as frequently as every five weeks, the optimal response of inflation and of the long-run tax rate are much closer to those in the baseline case than those under fully flexible prices. Likewise, in contrast to the monetary policy literature with lumpsum taxes, the authors find that, in their model, a government spending shock creating fiscal stress affects the optimal path of inflation and the output gap.

The authors set up targeting rules for the monetary and fiscal authorities in the form of commitments to maximize social welfare by adjusting the short-term interest rate and the tax rate, respectively. And each authority simultaneously makes the projected paths of inflation and the output gap (the target variables) satisfy the attainment of a unique, nonexplosive, rational-expectations equilibrium. Both monetary and fiscal policy can be used to stabilize an output gap that measures the perturbations from sticky prices and from distortionary taxes (taxes that are scaled to some payer variable such as income and that therefore influence, or distort, the payer's economic deci- sions); and fiscal policy can be used to address inflation because distortionary taxes affect real marginal costs and thus aggregate supply. Hence, monetary policy should take account of the requirements for government solvency, and fiscal policy should attend to its influence on inflation.

\section{Athey, Atkeson, and Kehoe}

In "The Optimal Degree of Monetary Policy Discretion," Athey, Atkeson, and Kehoe note that, according to most of the academic literature, there is no justification for policy discretion unless the central bank has important private information, information not available to the private sector. Acting to maximize social welfare, the central bank achieves the best outcomes when it follows a rule based on publicly observable data. There is scope for debate about the optimal degree of discretion if the central bank does have information. The question is this: How much risk of policy opportunism (boosting output through inflation surprises) should be tolerated to allow the central bank discretion to act on its private information?

In the authors' model, the central bank has private information on the state of the economy that determines society's preferred level of inflation. If this state is low, society desires low inflation; if it is high, society desires high inflation. In each period, private agents set their nominal wages before the monetary authority sets the inflation rate. This timing gives the central bank an incentive to engineer surprise inflation to reduce real wages and thereby lower unemployment toward its optimal level.

The optimal policy takes the form of an inflation cap. The benefit of reducing the cap is a decrease in the latitude for policy opportunism. The cost is a decrease in the scope for the central bank to use its private information to stabilize the economy. The cap is chosen low enough so that the cost of any further reduction just matches the benefit. One interpretation of the cap is that it is the optimal inflation target.

The main theoretical contribution of the paper is to make clear what information is required to choose the optimal (time-varying) inflation cap. It is remarkable that under some common assumptions the level of the cap depends only on the central bank's report on the current state of the economy. Otherwise it depends on reports on both current and past states.

The main practical contribution is to forcefully restate the argument that the case for central bank discretion rests on the assumption that the central bank has important private information. 


\section{Galí, López-Salido, and Vallés}

In most macroeconomic models, say Galí, LópezSalido, and Vallés in "Understanding the Effects of Government Spending on Consumption," a rise in government purchases of goods and services will tend to expand output. But the strength of that tendency varies greatly across types of models. The differences are rooted in alternative assumptions about how consumers react to the rise in current income attributable to the rise in government spending. In neoclassical (real-business-cycle, or RBC) models, consumers are assumed to spend according to a measure of their lifetime resources. A further common assumption is that, when government spending rises, these consumers will look ahead, in so-called Ricardian fashion, and anticipate that the present value of their after-tax lifetime income will fall because taxes will rise at some point to finance the higher government spending. Their anticipation of lower future income causes them to reduce their consumption immediately. But the supply of labor grows, real wages fall, and employment and output grow.

In traditional Keynesian models, consumers are not forward looking. They spend according to their current disposable income rather than their estimate of lifetime resources. Thus, an increase in government spending can directly increase output because higher demand from government need not be offset by lower demand from consumers. If the higher government spending is sufficiently financed by borrowing, it raises consumer income and is thus augmented by an increase in consumer demand. If the money supply is fixed, interest rates rise and investment falls; in contrast, an accommodation of the output expansion by the central bank will, depending on the extent of the policy easing, moderate or eliminate the investment decline.

In a review of the empirical evidence and through an investigation of their own, the authors find that, indeed, a rise in government spending leads to a significant increase in consumption and to little change, or a fall, in investment. They propose a general equilibrium model in which Ricardian and non-Ricardian consumers coexist and prices are sticky. The authors argue that both price stickiness and the existence of non-Ricardian consumers are necessary for an increase in government spending to raise consumption. Price stickiness lowers markups and allows real wages to rise along with employment; in turn, non-Ricardian consumers will respond to their higher income by increasing their consumption. The authors find that, for plausible settings for the proportion of non-Ricardian consumers, the degree of price stickiness, and the extent of debt financing, their model's results accord with empirical findings.

The model assumes that the taxes imposed to finance the rise in government spending are lumpsum, that is, they are the same dollar amount for each taxpayer. The authors leave to future research the question of how the model would respond if taxpayer liability varied with income.

\section{INTERNATIONAL LINKAGES}

The conference's third session, "International Linkages," featured three papers on the consequences of various economic policies and market structures in open economies. Nicoletta Batini, Paul Levine, and Joseph Pearlman look for the conditions under which central banks in open economies could effectively set policy according to a rule based on expected inflation. Tamim Bayoumi, Douglas Laxton, and Paolo Pesenti consider the efficiency gains in the industrial countries that could be expected from an increase in competition among businesses and workers in the euro area. And Michael Ehrmann and Marcel Fratzscher investigate whether the interdependence of the U.S. and euro-area money markets has increased since the advent of the European Economic and Monetary Union in 1999.

\section{Batini, Levine, and Pearlman}

Much work has been devoted to modeling closed economies in which the monetary authority changes interest rates in response to changes in expected, rather than current, inflation. Such policy behavior matches that in the inflation-forecasting models maintained at the central banks of Canada and New Zealand and appears to be consistent with recent monetary policy in the United States and the euro area. A criticism of a rule that responds to expected inflation is that of indeterminacy - it can lead to any of several equilibriums, some of which have undesirable outcomes for household welfare. In "Indeterminacy with Inflation-Forecast-Based Rules in a TwoBloc Model," Batini, Levine, and Pearlman extend existing work on indeterminacy under such rules to the case in which economies are open.

Their study uses a New Keynesian (that is, sticky nominal wages and prices) general equilibrium model based on microeconomic foundations with two country blocs. In each bloc the monetary authority follows the same inflation-forecast-based (IFB) rule. The 
model includes two features-habit persistence in consumption and backward-looking wage and price indexing - to improve its ability to mimic fluctuations in output, prices, and nominal interest rates in the euro area and the United States; and it includes one feature-home bias in consumption patternsthat improves its tracking of real exchange rate fluctuations between the two blocs. The authors show that if the monetary authorities respond to inflation forecasts too far ahead, the IFB rule produces an indeterminate equilibrium no matter how aggressive the response is. They also find that indeterminacy arises more readily in an open economy than in a closed one. Finally, they find that indeterminacy in an open economy is more likely if the monetary authorities respond to expected consumer price inflation rather than to expected producer price inflation.

The authors consider the results arising from alternative choices of inflation horizons and of inflation indexes for use in the policy rule to be an important warning for the central banks of the United States and the euro area. The reason is that both authorities seem to focus primarily on medium-term consumer price inflation expectations, thereby compounding the possibility of indeterminacy.

\section{Bayoumi, Laxton, and Pesenti}

Overregulation in Europe's product and labor markets is currently a leading explanation for the euro area's lower income per capita relative to the United States, and the reduction of such impediments has become a major policy topic in Europe. Bayoumi, Laxton, and Pesenti employ a version of the Global Economy Model (GEM) of the International Monetary Fund to examine the potential benefits from such deregulation. GEM provides for imperfect competition through markups in prices and wages above marginal costs and marginal output; the markups decrease as the substitutability of goods and inputs (that is, competition) increases. In the authors' twobloc version of GEM, one bloc is calibrated with euro-area data, and the other, which represents the rest of the industrialized world, is calibrated with U.S. data.

The resulting study, “When Leaner Isn't Meaner: Measuring Benefits and Spillovers of Greater Competition in Europe," simulates greater competition in the euro area by lowering euro-area markups in the model to the level of those in United States. With greater competition, businesses and workers in the euro area are less able to restrict their respective supplies. Accordingly, output and consumption increase strongly in the euro area; in the rest of the industrialized world, output increases somewhat, and consumption increases more than output because of an improvement in the terms of trade. Moreover, the authors show that, because greater competition improves the flexibility of wages and prices in the euro area, the central bank there faces an improved tradeoff between inflation and the output gap.

The markups employed in the model are based on empirically estimated data from both the United States and Europe, and the simulation results cover ten years. The authors emphasize that the quantitative results represent only an initial estimate subject to further refinements. These results show that, over the ten-year period, euro-area output per capita rises about $12^{1 / 2}$ percent above baseline (the level of output per capita if markups are not changed), and U.S.-calibrated output rises about 1 percent above baseline. The combined result closes about one-half of the per capita output gap between the two blocs. Euro-area consumption per capita rises about 8 percent above baseline. Accounting for the disutility of the rise in labor effort, welfare increases about $2 \frac{1}{2}$ percent. Consumption and welfare in the other bloc rise about $1 \frac{1 / 4}{4}$ percent because of an improvement in the terms of trade with the euro area. Finally, the tradeoff facing the euro-area monetary authority also improves because of a one-third reduction, relative to baseline, in the sacrifice ratio-the amount of output lost by lowering inflation 1 percentage point. Robustness checks indicate that the effect on the euro area economy is relatively invariant to alternative assumptions about key parameters but that the spillovers to the rest of the world are sensitive to these assumptions.

\section{Ehrmann and Fratzscher}

An extensive literature has documented the influence of domestic economic news on domestic interest rates and asset prices. In "Equal Size, Equal Role? Interest Rate Interdependence between the Euro Area and the United States," Ehrmann and Fratzscher investigate the international extent of such influence by looking at economic news and the behavior of interest rates in Germany and the United States from 1993 through 1998 and in the euro area and the United States from 1999 through February 2003. The paper attempts to measure the degree to which foreign news moves financial markets and whether U.S. and European financial markets have become more interdependent since the 1999 launch of the European Economic and Monetary Union (EMU). By 
examining the correlation of announcements of economic fundamentals in the two regions, the authors also assess whether greater financial interdependence reflects a broader increase in economic interdependence between the two regions.

In studying daily money market rates for the 19932003 period, the authors find that money market linkages have strongly increased with the arrival of the EMU. During trading hours, the changes in money market rates in the euro area generally spill over to the United States and vice versa. Although developments in one market are not completely reflected in the other market, the linkage is highly significant in statistical tests. Moreover, the EMU has changed this relationship between markets in two dimensions. First, the systematic reaction of U.S. markets to developments in Europe can be found only with the start of the EMU. Through statistical testing methods, this increased linkage can be dated to June 1998 , the time by which markets were certain that the EMU would become a reality. Second, the extent to which market movements in the United States are reflected in the euro-area money market has increased. This effect, too, is linked with the formation of the EMU.

The authors go beyond the linkages that can be observed each trading day to study the extent to which markets react to the release of macroeconomic news or monetary policy decisions in the other economy. European markets are found to react to certain macroeconomic news about the U.S. economy. This phenomenon can be identified particularly for releases of U.S. data on retail sales, consumer confidence, industrial production, and the survey from the National Association of Purchasing Managementthat is, mostly announcements that are known as leading indicators for the U.S. economy. Importantly, this reaction of euro-area money markets started only with the advent of the EMU.

The results raise the question of why the U.S. and euro-area money markets have become so much more interdependent and, in particular, why some U.S. news has become an important determinant of euroarea interest rates. This finding may reflect growing real integration and interdependence between the two economies. A second interpretation ties the result to the timing of the news releases in each economyU.S. macroeconomic news is released significantly ahead of the corresponding news in Germany and the euro area. Testing for this hypothesis, the authors show that U.S. announcements have, over time, become strong leading indicators for the euro-area economy. Accordingly, investors in recent years may be paying increasing attention to U.S. news to learn about the prospects of the euro-area economy. In short, according to the authors, their findings suggest that the U.S. and euro-area money markets have become significantly more interdependent since the start of the EMU, a development at least partly due to an increase in the real integration of the U.S. and euro-area economies in recent years.

\section{OPTIMAL MONETARY POLICY}

The fourth and final session of the conference, "Optimal Monetary Policy," featured two papers. In the first paper, Robert G. King and Alexander L. Wolman investigate the problem of multiple equilibriums under a discretionary monetary policy. In the second, Ester Faia and Tommaso Monacelli consider optimal monetary policy in a world in which policymakers in each country have an incentive to improve the welfare of domestic residents by manipulating the terms of trade in their own favor.

\section{King and Wolman}

Those who advocate policy rules criticize discretionary monetary policy mainly because, through attempts to stimulate output with surprise policy easings, it leads to higher average inflation than does a policy rule. In neoclassical models, such attempts can be futile because private-sector agents come to expect the behavior; as a result, inflation is higher, but output remains essentially unchanged. The inflationary bias of discretionary monetary policy can also be derived from New Keynesian models, in which output is inefficiently low because of imperfect competition, prices are set for a fixed length of time, and agents have differing repricing schedules (staggered pricing).

In their paper, "Monetary Discretion, Pricing Complementarity, and Dynamic Multiple Equilibria," King and Wolman demonstrate, in a New Keynesian setting, that besides producing high inflation, discretion has a further adverse consequence. It can produce multiple equilibriums that lead to excess volatility in prices and output because of changing beliefs of private agents. The volatility arises because forward-looking price setting by firms interacts with discretionary behavior by a monetary authority attempting to maximize private welfare.

In the authors' model, firms set prices for two periods by applying a markup to their nominal marginal costs in the current period and their expected nominal marginal costs in the next period. In each 
period, one-half of all firms set their prices, and the other half hold them steady at the level set in the preceding period. Optimal behavior on the part of the discretionary monetary authority implies that it chooses the size of the money stock in each period to be proportional to prices set by firms in the previous period.

If firms resetting prices in the current period expect the money supply to be higher in the next period, they will raise their prices because the increase in the money stock in the next period will act to increase their nominal marginal costs in the next period. The expectation of a higher money stock can be selffulfilling because the monetary authority will increase the stock in the next period precisely because prices were raised in the current period. Hence, besides discretionary policy's having an inflationary bias, the interaction of beliefs and discretionary policy sets off inefficient fluctuations in economic activity.

\section{Faia and Monacelli}

In "Ramsey Monetary Policy and International Relative Prices," Faia and Monacelli examine optimal monetary policy in a two-country New Keynesian model (sticky prices, imperfect competition). The authors use a Ramsey framework, familiar from the optimal-taxation literature, which, they note, is not often deployed in analyses of monetary and exchange rate policy in open economies. The Ramsey approach allows the authors to consider a much more general specification of household preferences than previously considered. Moreover, the authors incorporate a dynamic specification of price-setting that affords them a more coherent framework for assessing the benefits of policies that are set according to rules rather than discretion.

In the authors' model, policymakers maximize the welfare of domestic residents subject to the constraints of the competitive economy. Because prices are sticky, policymakers in each country have an incentive to implement policies that manipulate the terms of trade in their own country's favor (that is, improve the domestic tradeoff between consumption and production by raising the price of home goods relative to that of foreign goods).

The authors show that the equilibrium behavior that emerges when domestic policymakers act in such an uncoordinated manner is quite different from that which would obtain if a single "world social planner" formulated policy for the two countries. In particular, prices are much less stable than if there were a world social planner. Moreover, only under the coordinated policy would both countries target the same allocation of resources that would occur under flexible prices.

The authors indicate three restrictions of the model that could be amended in future work to allow more realistic adjustments in the current account: (1) The law of one price holds continuously, (2) households fully share risk via international financial markets, and (3) households invest in only financial, not physical, assets.

\section{CONFERENCE PAPERS}

Athey, Susan, Andrew Atkeson, and Patrick J. Kehoe. "The Optimal Degree of Monetary Policy Discretion."

Batini, Nicoletta, Paul Levine, and Joseph Pearlman. "Interdeterminacy with Inflation-Forecast-Based Rules in a Two-Bloc Model."

Bayoumi, Tamim, Douglas Laxton, and Paolo Pesenti. "When Leaner Isn't Meaner: Measuring Benefits and Spillovers of Greater Competition in Europe."

Benigno, Pierpaolo, and Michael Woodford. "Optimal Monetary and Fiscal Policy: A LinearQuadratic Approach.”

Collard, Fabrice, and Harris Dellas. "The Great Inflation of the 1970s."

Ehrmann, Michael, and Marcel Fratzscher. "Equal Size, Equal Role? Interest Rate Interdependence between the Euro Area and the United States."

Faia, Ester, and Tommaso Monacelli. "Ramsey Monetary Policy and International Relative Prices.”

Galí, Jordi, J. David López-Salido, and Javier Vallés. "Understanding the Effects of Government Spending on Consumption."

King, Robert G., and Alexander L. Wolman. "Monetary Discretion, Pricing Complementarity, and Dynamic Multiple Equilibria."

Orphanides, Athanasios, and John C. Williams. "The Decline of Activist Stabilization Policy: Natural Rate Misperceptions, Learning, and Expectations." 


\section{AUTHORS}

Affiliations are as of the time of the conference.

Susan Athey

Stanford University and National Bureau

of Economic Research

Andrew Atkeson

University of California-Los Angeles, Federal

Reserve Bank of Minneapolis, and National Bureau of Economic Research

Nicoletta Batini

Bank of England

Tamim Bayoumi

International Monetary Fund

Pierpaolo Benigno

New York University

Fabrice Collard

Groupe de Recherche en Economie Mathématique et Quantitative (Université de Toulouse and Centre National de la Recherche Scientifique)

Harris Dellas

University of Bern

Michael Ehrmann

European Central Bank

Ester Faia

Universitat Pompeu Fabra

Marcel Fratzscher

European Central Bank

Jordi Galí

Centre de Recerca en Economia Internacional and Universitat Pompeu Fabra

Patrick J. Kehoe

Federal Reserve Bank of Minneapolis, University of Minnesota, and National Bureau of Economic Research
Robert G. King

Boston University and National Bureau of Economic Research

Douglas Laxton

International Monetary Fund

Paul Levine

University of Surrey

J. David López-Salido

Banco de España

Tommaso Monacelli

Innocenzo Gasparini Institute for Economic Research (Università Bocconi) and Centre for Economic Policy Research

Athanasios Orphanides

Board of Governors of the Federal Reserve System

Joseph Pearlman

London Metropolitan University

Paolo Pesenti

Federal Reserve Bank of New York and National

Bureau of Economic Research

Javier Vallés

Banco de España

John C. Williams

Federal Reserve Bank of San Francisco

Alexander L. Wolman

Federal Reserve Bank of Richmond

Michael Woodford

Princeton University 